\title{
Synthesis of carbon-supported PdSn-SnO2 nanoparticles with different degrees of interfacial contact and enhanced catalytic activities for formic acid oxidation
}

Hui Wang, Ziyue Liu, Yanjiao Ma, Key Julian, Shan Ji, Vladimir Linkov and Rongfang Wang

\begin{abstract}
The conjunction of the $\mathrm{PdSn}$ alloy and $\mathrm{SnO}_{2}$ is of interest for improving catalytic activity in formic acid oxidation (FAO). Here, we report the synthesis of $\mathrm{PdSn}-\mathrm{SnO}_{2}$ nanoparticles and a study of their catalytic FAO activity. Different degrees of interfacial contact between $\mathrm{SnO}_{2}$ and PdSn were obtained using two different stabilizers (sodium citrate and EDTA) during the reduction process in catalyst preparation. Compared to the $\mathrm{PdSn}$ alloy, $\mathrm{PdSn}-\mathrm{SnO}_{2}$ supported on carbon black showed enhanced FAO catalytic activity due to the presence of $\mathrm{SnO}_{2}$ species. It was also found that interfacial contact between the PdSn alloy and the $\mathrm{SnO}_{2}$ phase has an impact on the activity towards $\mathrm{CO}$ oxidation and FAO.
\end{abstract}

\section{Introduction}

It is well established that $\mathrm{Pd}$ metal catalysts, being much less prone to $\mathrm{CO}$ poisoning and related deactivation, perform better than Pt catalysts in formic acid oxidation (FAO). ${ }^{1-3}$ Combining Pd with a second noble metal component (such as $\mathrm{Au}, 4 \mathrm{Pt} 5$ and $\mathrm{Ru},{ }^{6}$ etc.) is an effective way to enhance FAO activity, but the cost of such noble metal combinations still remains high. Consequently, Pd alloying with far cheaper non-noble metals (such as $\mathrm{Fe},{ }^{7} \mathrm{Co},{ }^{8} \mathrm{Ni},{ }^{-11} \mathrm{Cu},{ }^{12,13}$ and $\mathrm{Sn}^{14-16}$ ) has generated obvious interest, with steady improvements in catalytic activity and tolerance to $\mathrm{CO}$ poisoning being made through ongoing research.

Yet another promising route to enhance Pd catalyst activity is through the addition of transition metal oxides either as a component of the catalyst or as a support. ${ }^{17-19}$ For example, both the catalytic FAO activity and $\mathrm{CO}$ tolerance of $\mathrm{Pd} / \mathrm{C}$ catalysts have been enhanced through addition of $\mathrm{MoO}_{x}$, which is attributed to the hydrogen spillover effect on $\mathrm{MoO}_{x} \cdot{ }^{20,21}$ Similarly, $\mathrm{SnO}_{2}$ as a support for the Pd catalyst has shown improved activity, ${ }^{22}$ as has $\mathrm{SnO}_{2}$ dispersed in polyindole which has reportedly good $\mathrm{CO}$ tolerance during $\mathrm{FAO}$ and follows a direct pathway to convert it into $\mathrm{CO}_{2} .{ }^{23}$ 
In addition, other composite structures, where the alloy and metal oxide are in close proximity, such as the composite of $\mathrm{RuO} \cdot x \mathrm{H} \mathrm{O}$ with the $\mathrm{PtRu}$ alloy, have been reported to improve methanol oxidation activity in direct methanol fuel cells. Huang et al. reported enhanced $\mathrm{PtRu} / \mathrm{C}$ catalyst activity by oxidation treatments resulting in the formation of intimate contact between $\mathrm{RuO}_{2}$ crystalline phases and the PtRu alloy, 24,25 a phenomenon that has also been demonstrated elsewhere. ${ }^{26}$ To further understand the relationship between the $\mathrm{RuO}_{x}$ and catalytic activity, Shyam et al. investigated the effect of $\mathrm{RuO}_{x}$ island size on the activity of the PtRu/C catalyst, and found that larger $\mathrm{Ru}$ islands were less susceptible to dissolution, induced a larger ligand effect, and were ultimately much more stable. ${ }^{27}$ Given these observations, the effect of other metal oxides in such roles begs the need for similar thorough investigation.

In the present study, the effect of $\mathrm{SnO}_{2}$ on PdSn activity in FAO was investigated. PdSn$\mathrm{SnO}_{2}$ and $\mathrm{PdSn}-\mathrm{SnO}_{2}$-island nano- particles supported on carbon were prepared by polyhydric alcohol reduction with different stabilizers. We report for the first time preparation of a hetero-structure, $\mathrm{SnO}_{2}$ island, in intimate contact with $\mathrm{PdSn}$ nanoparticles, using a one-pot method. It was found that the degree of interfacial contact between $\mathrm{PdSn}$ and $\mathrm{SnO}_{2}$ influences FOA catalytic performance, and that $\mathrm{SnO}_{2}$ islands have a strong enhancing effect on catalyst activity.

\section{Experimental procedures}

\subsection{Catalystpreparation}

To prepare $\mathrm{PdSn}-\mathrm{SnO}_{2}$ supported on carbon $\left(\mathrm{PdSn}-\mathrm{SnO}_{2} / \mathrm{C}\right), 15.6 \mathrm{mg}$ of $\mathrm{PdCl}_{2}$ and $46.2 \mathrm{mg}$ of $\mathrm{SnCl}_{4} \cdot 5 \mathrm{H}_{2} \mathrm{O}$ were dissolved in $30 \mathrm{~mL}$ of $\mathrm{EG}$ in a $100 \mathrm{~mL}$ flask, followed by the addition of $288.2 \mathrm{mg}$ of sodium citrate (stabilizer) with stirring for $0.5 \mathrm{~h}$. Then, $100 \mathrm{mg}$ of pretreated carbon black (Vulcan $\mathrm{XC}-72 \mathrm{R}$ ) was added with $\mathrm{pH}$ adjusted to 10 by the drop-wise addition of a $5 \mathrm{wt} \% \mathrm{KOH}-\mathrm{EG}$ solution with vigorous stirring. The mixture was maintained at $1601 \mathrm{C}$ for $8 \mathrm{~h}$ and the product collected by filtration, then washed four times with deionized water and finally dried in air at $60 \mathrm{CC}$ for $5 \mathrm{~h}$. To prepare $\mathrm{PdSn}-\mathrm{SnO}_{2}$-islands supported on carbon $\left(\mathrm{PdSn}-\mathrm{SnO}_{2}\right.$-island/C), the above procedure and materials were used but with replacement of sodium citrate by $401.8 \mathrm{mg}$ of ethylene diamine tetra-acetic acid (EDTA).

For a comparison, $\mathrm{PdSn}$ supported on carbon ( $\mathrm{PdSn} / \mathrm{C}), \mathrm{Pd} / \mathrm{C}$ and $\mathrm{SnO}_{2} / \mathrm{C}$ catalysts were also prepared. $\mathrm{PdSn} / \mathrm{C}$ was prepared as follows: palladium chloride $\left(\mathrm{PdCl}_{2}\right)(19.7 \mathrm{mg})$ was dissolved in a small amount of concentrated $\mathrm{HCl}$ to form $\mathrm{H}_{2} \mathrm{PdCl}_{4}$ aqueous solution, then stannic chloride pentahydrate $\left(\mathrm{SnCl}_{4} \cdot{ }_{5} \mathrm{H}_{2} \mathrm{O}\right)(38.9 \mathrm{mg})$ dissolved in $30 \mathrm{~mL}$ ethylene glycol (EG) was added and stirred for $0.5 \mathrm{~h}$. Pretreated carbon black Vulcan XC-72R (100 $\mathrm{mg}$ ) was added to the mixture under stirring conditions and adjusted to $\mathrm{pH} \mathbf{E} 9$ by the drop-wise addition of a $5 \mathrm{wt} \% \mathrm{KOH}-\mathrm{EG}$ solution with vigorous stirring. The mixture was then maintained at $1601 \mathrm{C}$ for $8 \mathrm{~h}$, and the powder collected by filtration, washed several times with deionised water and dried in air at $601 \mathrm{C}$ for $5 \mathrm{~h}$. The procedure for preparing

\section{http://repository.uwc.ac.za}


$\mathrm{Pd} / \mathrm{C}$ is the same as the method used in the previous work 28

and the preparation of $\mathrm{SnO}_{2} / \mathrm{C}$ is the same as the procedure used by Wang et al. ${ }^{29}$

\subsection{Characterization}

Particle size and morphology of the catalysts were analyzed by transmission electron microscopy (TEM) using a JEM-2010 microscope. X-ray diffraction (XRD) patterns of the catalysts were characterized on a Shimadzu XD-3A (Japan) goniometer, using $\mathrm{Cu} \mathrm{Ka}$ radiation operated at $40 \mathrm{kV}$ and $35 \mathrm{~mA}$ at room temperature. X-ray photoelectron spectroscopy (XPS) was carried out on a PHI-5702 multifunctional X-ray photoelectron spectrometer (American). The average chemical compositions of the catalysts were determined using an IRIS advantage inductively coupled plasma atomic emission spectroscopy (ICP-AES) system (Thermo, America).

Electrochemical tests were carried out on a CHI650D electro- chemical workstation. A conventional three-electrode cell was used, comprising a $\mathrm{Ag} / \mathrm{AgCl}\left(3 \mathrm{~mol} \mathrm{~L}^{-1} \mathrm{KCl}\right)$ reference electrode, a platinum wire counter electrode, and a modified glass carbon working electrode ( $5 \mathrm{~mm}$ in diameter). Before each measure- ment, the solution was saturated with $\mathrm{N}_{2}$ gas. The catalyst ink was produced by mixing $5 \mathrm{mg}$ of the catalyst ultrasonically in $1 \mathrm{~mL}$ Nafion-ethanol (0.25\% Nafion). Catalyst layer preparations on the glassy carbon working electrode were made using $8 \mathrm{~mL}$ suspensions that were then dried in air. All measurements were made at ambient temperature.

\section{Results and discussion}

The XRD pattern of the $\mathrm{PdSn}-\mathrm{SnO}_{2} / \mathrm{C}$ catalyst prepared using sodium citrate as the stabilizer is shown in Fig. 1a. The diffraction peak at ca. 251 is associated with the (o o 2) reflection of the hexagonal structure of Vulcan XC-72 carbon. The typical character of a crystalline Pd face-centered cubic (fcc) phase is confirmation of the (1 111$),\left(\begin{array}{lll}2 & 0 & 0\end{array}\right),\left(\begin{array}{lll}2 & 2 & 0\end{array}\right)$, and ( $\left.\begin{array}{lll}3 & 1 & 1\end{array}\right)$ reflections at about 401, 471, 681 and 821, respectively. 30 The peaks located at 26.61 and 33.91 tetragonal $\mathrm{SnO}_{2}$ phase, while the peak at 42.31 corresponds to the orthorhombic $\mathrm{SnO}_{2}$ phase. 31,32 On the other hand, the $\left(\begin{array}{lll}1 & 1 & 1\end{array}\right)$ peak shifted to a slightly lower angle by E0.271, suggesting that Sn interacts with Pd resulting in Pd-Sn alloy formation.33 

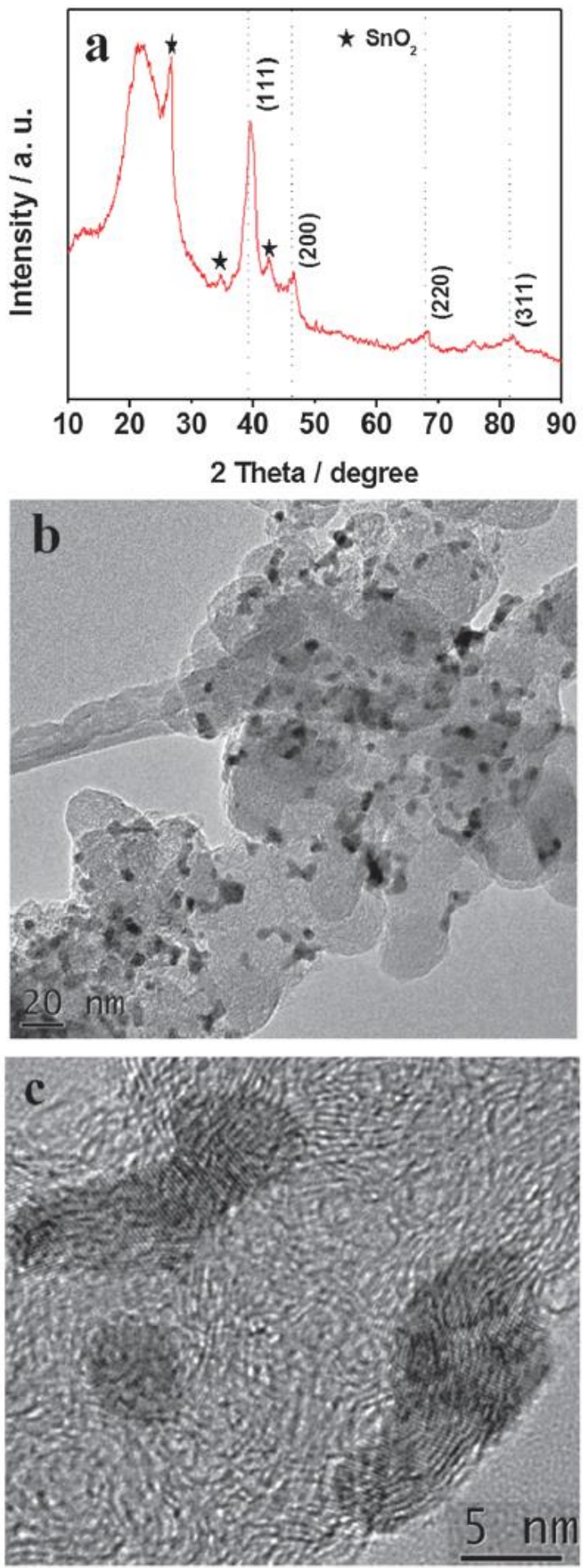

Fig. 1 (a) $\mathrm{XRD}$ pattern of the $\mathrm{PdSn}-\mathrm{SnO}_{2} / \mathrm{C}$ catalyst, the vertical dot lines represent the typical reflection of fcc Pd; (b) TEM and (c) HRTEM images of the $\mathrm{PdSn}-\mathrm{SnO}_{2} / \mathrm{C}$ catalyst. 
The TEM image of $\mathrm{PdSn}-\mathrm{SnO}_{2} / \mathrm{C}$ (Fig. 1b) shows strip shaped catalyst nanoparticles homogeneously dispersed on the surface of carbon. The lengths of the strips range between 3 and $12 \mathrm{~nm}$, with a width of ca. $3 \mathrm{~nm}$. The fine structure of the strips was further characterized through high resolution transmission electron microscopy (HRTEM), as shown in Fig. 1c. We could not observe the grain boundaries in the strip. These results indicate that $\mathrm{SnO}_{2}$ coexists with $\mathrm{PdSn}$, which may be due to the crystal grains of $\mathrm{SnO}_{2}$ being too small to be observed. From the above results, we can conclude that the composite structure of the PdSn$\mathrm{SnO}_{2} / \mathrm{C}$ catalyst with the strip morphology is formed and $\mathrm{PdSn}-\mathrm{SnO}_{2}$ is a $\mathrm{PdSn}$ alloy with phase-separated $\mathrm{SnO}_{2}$. The interface between $\mathrm{PdSn}$ and $\mathrm{SnO}_{2}$ is not observed. The composition of the catalyst was determined by ICP-AES analysis, with a metal loading of $19.7 \mathrm{wt} \%$ and a $\mathrm{Pd}: \mathrm{Sn}$ atomic ratio of $1: 1.47$.

The XRD pattern of the PdSn-SnO ${ }_{2}$-islands/C catalyst pre- pared using EDTA as the stabilizer is shown in Fig. 2a. The ( 0 o 2) reflection of carbon is observed at ca. 251 and the (1 11 1), (2 0 o ), (2 20 ), and (3 11 ) reflections of fcc Pd at about 401, 471, 681 and 821, respectively. The weak reflections (marked with a black star) observed at 33.91 and 52.01 correspond to the (101) and (211) reflections of the tetragonal $\mathrm{SnO}_{2}$ phase.31,32 The peak located at 26.61, corresponding to the $(110)$ reflection of the tetragonal $\mathrm{SnO}_{2}$ phase, cannot be observed, perhaps because of the overlap with the (o o 2) reflection of carbon. At the same time, a positive shift of ca. 0.201 for the (1 1 1) peak suggests the formation of the PdSn alloy.

The TEM image of the as-prepared $\mathrm{PdSn}-\mathrm{SnO}_{2}$-islands/C catalyst (see Fig. 2b) shows highly uniform dispersion of parti- cles with irregular sphere shaped morphology. However, we found that the very small particles connect with the edges of large particles (see particles illustrated with a red circle). The fine structure of the particles was further characterized using HRTEM, Fig. 2c and d. For observation, we choose two kinds of the particles, one lying between carbon particles (Fig. 2c), and the other located on the edge of carbon particles (see Fig. 2d). In Fig. 2c and d, the interfaces between $\mathrm{PdSn}$ and $\mathrm{SnO}_{2}$ can be clearly seen, which indicates a hetero-structure, comprising $\mathrm{SnO}_{2}$ islands in intimate contact with $\mathrm{PdSn}$ nanoparticles. It should be noted that the size of the $\mathrm{SnO}_{2}$ islands is not uniform. Catalyst composition by ICP-AES analysis shows the metal load- ing to be 19.5 wt\% with a Pd : Sn atomic ratio of $1: 1.46$.

The XRD pattern and TEM image of the prepared PdSn/C catalyst are shown in Fig. 3.

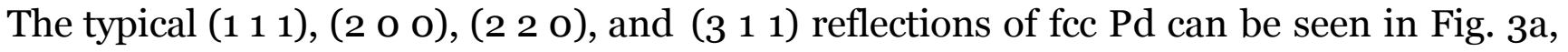
and the Bo.251 positive shift confirms the formation of the PdSn alloy. Fig. $3 \mathrm{~b}$ shows that the elliptical PdSn nanoparticles of 3-7 $\mathrm{nm}$ are uniformly dispersed on the surface of carbon black. The catalyst composition determined using ICP-AES analysis shows that the metal loading is 19.7 wt\% with a $\mathrm{Pd}: \mathrm{Sn}$ atomic ratio of $1: 1$. 
XPS was employed to investigate the nature of surface species for the $\mathrm{PdSn}-\mathrm{SnO}_{2} / \mathrm{C}$, $\mathrm{PdSn}-\mathrm{SnO}_{2}$-island/C and $\mathrm{PdSn} / \mathrm{C}$ catalysts. The $\mathrm{Pd} 3 \mathrm{~d}$ photoelectron core-level spectra of $\mathrm{PdSn}-\mathrm{SnO}_{2} / \mathrm{C}, \mathrm{PdSn}-\mathrm{SnO}_{2}$-island/C and $\mathrm{PdSn} / \mathrm{C}$ catalysts are shown in Fig. 4.

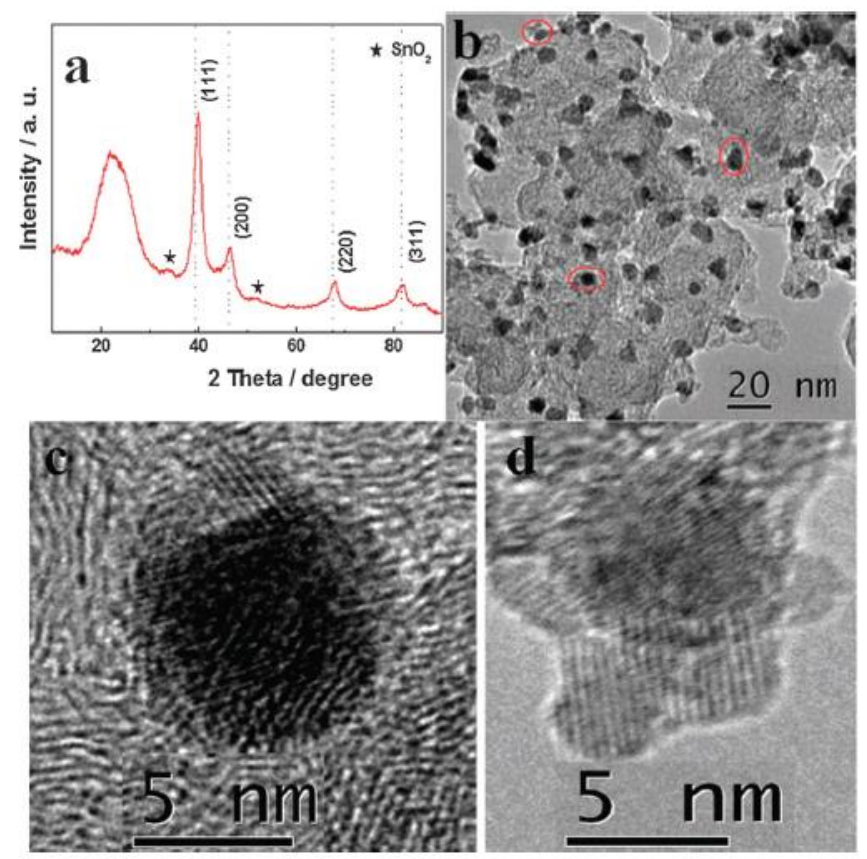

Fig. 2 (a) XRD pattern of the $\mathrm{PdSn}-\mathrm{SnO}_{2}$-islands/C catalyst, the vertical dot lines represent the typical reflection of fcc Pd; (b) TEM and ( $c$ and d) HRTEM images of the $\mathrm{PdSn}-\mathrm{SnO}_{2}$-islands/ $\mathrm{C}$ catalyst.
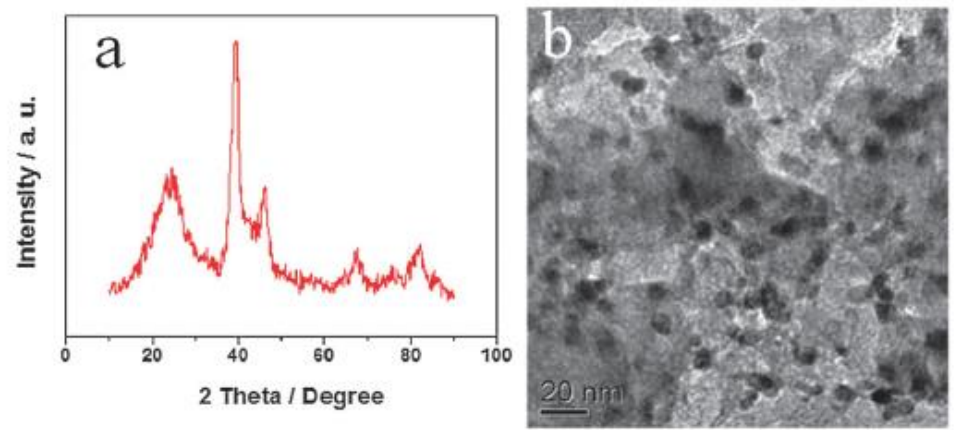

Fig. 3 (a) The XRD pattern and (b) TEM image of the PdSn/C catalyst. 


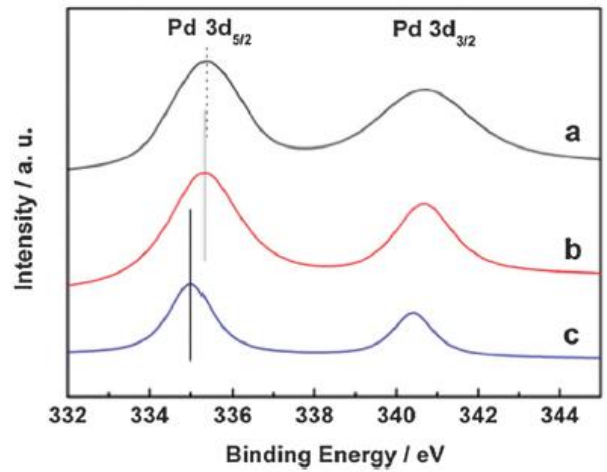

Fig. 4 XPS spectra for the Pd $3 d$ core-level of the nanoparticles of the samples (a) $\mathrm{PdSn}-\mathrm{SnO}_{2}$-islands/C, (b) PdSn-SnO $/ 2$, and (c) PdSn/C. The maximum of the $\mathrm{Pd} 3 \mathrm{~d}_{5 / 2}$ peak is used as the measure of the binding energy and is indicated by the vertical lines.

Table $1 \mathrm{Pd} 3 \mathrm{~d}$ and $\mathrm{Sn} 3 \mathrm{~d}_{5 / 2}$ binding energy of the three catalysts

\begin{tabular}{|c|c|c|c|c|c|}
\hline \multirow[b]{2}{*}{ Catalyst } & \multirow[b]{2}{*}{$\operatorname{Pd} 3 \mathrm{~d}_{5 / 2} / \mathrm{eV}$} & \multirow[b]{2}{*}{$\mathrm{Pd} 3 \mathrm{~d}_{3 / 2} / \mathrm{eV}$} & \multicolumn{3}{|c|}{$\underline{\text { Sn } 3 d_{5 / 2}}$} \\
\hline & & & $\operatorname{Sn}(0)$ & $\operatorname{Sn}($ II) & $\operatorname{Sn}(\mathrm{IV})$ \\
\hline $\mathrm{PdSn}-\mathrm{SnO}_{2}$-islands/C & 335.3 & 340.7 & 487.1 & 486.4 & 485.3 \\
\hline $\mathrm{PdSn}-\mathrm{SnO}_{2} / \mathrm{C}$ & 335.2 & 340.4 & 487.2 & 486.2 & 485.3 \\
\hline $\mathrm{PdSn} / \mathrm{C}$ & 335.0 & 340.4 & 468.0 & 486.0 & 485.2 \\
\hline $\mathrm{Pd}^{13}$ & 335.1 & - & & & \\
\hline
\end{tabular}

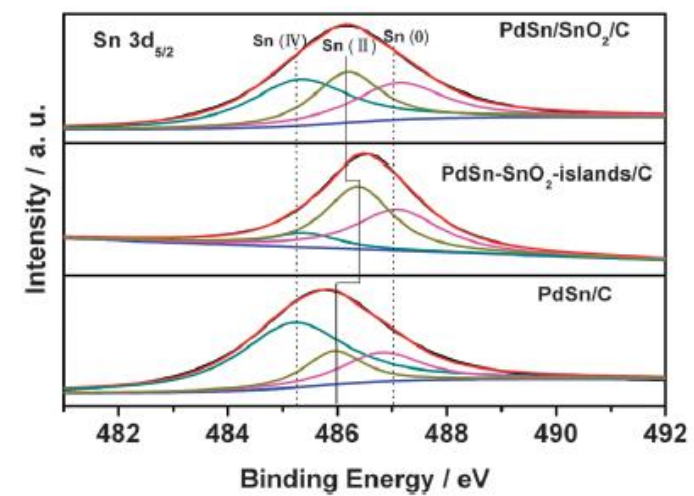

Fig. $5 \mathrm{Sn} 3 \mathrm{~d}_{5 / 2}$ core-level XPS spectra of $\mathrm{PdSn}-\mathrm{SnO}_{2} / \mathrm{C}, \mathrm{PdSn}-\mathrm{SnO}_{2}$-islands/C and $\mathrm{PdSn} / \mathrm{C}$ catalysts.

All of the spectra show two peaks corresponding to $\mathrm{Pd} 3 \mathrm{~d}_{5} / 2$ and $\mathrm{Pd} 3 \mathrm{~d}_{3} / 2$, which are characteristic peaks of Pd metal. The binding energies (BEs) of all peaks are listed in Table 1. Compared with the literature, ${ }^{20-22}$ it is found that most of the Pd in the catalysts Fig. 5 Sn $3 \mathrm{~d}_{5} / 2$ core-level XPS spectra of $\mathrm{PdSn}-\mathrm{SnO}_{2} / \mathrm{C}, \mathrm{PdSn}-\mathrm{SnO}_{2}$-islands/C and $\mathrm{PdSn} / \mathrm{C}$ catalysts exists as metallic $\mathrm{Pd}$ and there is only a small amount of $\mathrm{Pd}$ oxide. The $\mathrm{Pd}$ metal is easily oxidized to form $\mathrm{Pd}$ oxide under ambient conditions. ${ }^{20}$ Compared with the $\mathrm{PdSn} / \mathrm{C}$ catalyst, positive shifts of $\mathrm{BEs}$ for $\mathrm{PdSn}-\mathrm{SnO}_{2} / \mathrm{C}$ and $\mathrm{PdSn}-\mathrm{SnO}_{2}$-islands/C catalysts are observed. 
Based on the electronegativity series ( $\mathrm{Sn}, 1.96$; $\mathrm{Pd}, 2.20$ ), the addition of $\mathrm{Sn}$ in the PdSn system means that charge transfer occurs from $\mathrm{Sn}$ to $\mathrm{Pd}$, resulting in decrease in $\mathrm{Pd} \mathrm{BE}$, i.e. the negative shift of $\mathrm{Pd} 3 \mathrm{~d} \mathrm{BE}$ of PdSn. Moreover, the electronic effect of Sn increases with the increase of $\mathrm{Sn}$ content. ${ }^{16}$ The $\mathrm{Sn}$ contents in $\mathrm{PdSn}-\mathrm{SnO}_{2} / \mathrm{C}$ and $\mathrm{PdSn}-\mathrm{SnO}_{2}$ islands/C catalysts are higher than that of the PdSn/C catalyst, but a positive shift of $\mathrm{Pd} 3 \mathrm{~d}$ BE occurs. In the work of Feng et al., ${ }^{19}$ the interaction between Pd nanoparticles and the $\mathrm{CeO}_{2}$ particles leads to the positive shift of the Pd $3 \mathrm{~d}$ BEs. Similar results were also reported by other groups. ${ }^{2,34,35}$ Here, it could be presumed that there is an interaction between the $\mathrm{PdSn}$ phase and the $\mathrm{SnO}_{2}$ phase, i.e. the electronic structure of $\mathrm{Pd}$ is modified by both Sn species clearly shift to higher BE and follow in the order: $\mathrm{Pd} / \mathrm{C}$ $\mathrm{Pd} / \mathrm{C}$ o $\mathrm{PdSn} / \mathrm{C}$ o $\mathrm{PdSn}-\mathrm{SnO}_{2} / \mathrm{C}$ o PdSn-SnO 2 -islands/C. Changes in the $\mathrm{Sn}$ (II) $3 \mathrm{~d}$ core-level BEs suggest that electronic modification of the $\mathrm{Sn}(\mathrm{II}) \mathrm{O}$ species by interactions with the PdSn substrate are dependent on the component.

The relative atomic percentages of different Sn species, determined from the related peak areas, are illustrated in Fig. 6. Due to the presence of the $\mathrm{SnO}_{2}$ phase, the percentage of tin oxides in $\mathrm{PdSn}-\mathrm{SnO}_{2} / \mathrm{C}$ and $\mathrm{PdSn}-\mathrm{SnO}_{2}$-islands/C cata- lysts is much higher than that in the $\mathrm{PdSn} / \mathrm{C}$ catalyst and the percentage of $\mathrm{Sn}$ (II) species for the $\mathrm{PdSn}-\mathrm{SnO}_{2}$-islands/C catalyst is obviously higher than the $\mathrm{PdSn}-\mathrm{SnO}_{2} / \mathrm{C}$ catalyst. Based on the results calculated from the atom superposition and electron delocalization molecular orbital theory, Anderson et al. proposed that the $\mathrm{Sn}(\mathrm{II}) / \mathrm{Sn}(\mathrm{IV})$ redox couple is the main factor for the generation of $(\mathrm{OH})$ ads, which can promote the oxidation of $\mathrm{CO}$ in the process of FAO.

Compared to $\mathrm{PdSn} / \mathrm{C}$, the offset of $\mathrm{PdSn}-\mathrm{SnO}_{2}$-islands/C is $c a .0 .3 \mathrm{eV}$, which is larger than that of $\mathrm{PdSn}-\mathrm{SnO}_{2} / \mathrm{C}$. The BE shifts depend on the extent of d-hybridization. dHybridization forms stronger bonds than the bonds between the metal atoms, which reduces the potential of the metal to form strong bonds with adsorbed reactants. In turn, this change of the adsorbing bond strength to a nanoparticle is a key factor for the reactivity. $36-38$ Based on the above facts, the bonds with adsorbed reactants on PdSn$\mathrm{SnO}_{2}$-island nanoparticles would be weaker than $\mathrm{PdSn}-\mathrm{SnO}_{2}$ nanoparticles.

Sn $3 \mathrm{~d}_{5 / 2}$ XPS spectra of the three catalysts are shown in Fig. 5. In order to better understand the contribution of different states of Sn atoms, XPS Sn $3 \mathrm{~d}_{5} / 2$ peaks were deconvoluted The peak fitting analysis of Sn $3 \mathrm{~d}_{5} / 2$ XPS data shows that there are three overlapped peaks; the one with the lowest BE corresponds to metallic $\operatorname{Sn}(0)\left(3 \mathrm{~d}_{5} / 2=\right.$ $485.3 \pm 0.1 \mathrm{eV})$; the one with highest BE relates to fully oxidized $\mathrm{Sn}(\mathrm{IV})\left(3 \mathrm{~d}_{5} / 2=487.2 \pm\right.$ $0.1 \mathrm{eV})$ and the peak in between belongs to $\mathrm{Sn}(\mathrm{II})\left(3 \mathrm{~d}_{5} / 2=486.1 \pm 0.5 \mathrm{eV}\right) .39-41$ The core-level BE difference of $\mathrm{Sn}(\mathrm{o}), \mathrm{Sn}(\mathrm{IV})$ and $\mathrm{Sn}$ (II) is consistent with values reported in the literature.39-41 These results suggest the three Sn species existed on the surface for 
all three catalysts. The existence of three Sn species was also reported under other experimental conditions. 40,42 As shown in Fig. 5, the Sn $3 \mathrm{~d}_{5 / 2}$ peaks for $\mathrm{Sn}$ (II) species clearly shift to higher BE and follow in the order: $\mathrm{Pd} / \mathrm{C} \mathrm{Pd} / \mathrm{C}$ o PdSn/C o PdSn-SnO $2 / \mathrm{C}$ o PdSn-SnO 2 -islands/C. Changes in the Sn(II) 3d core-level BEs suggest that electronic modification of the $\mathrm{Sn}(\mathrm{II}) \mathrm{O}$ species by interactions with the PdSn substrate are dependent on the component.

The relative atomic percentages of different Sn species, determined from the related peak areas, are illustrated in Fig. 6. Due to the presence of the $\mathrm{SnO}_{2}$ phase, the percentage of tin oxides in $\mathrm{PdSn}-\mathrm{SnO}_{2} / \mathrm{C}$ and $\mathrm{PdSn}-\mathrm{SnO}_{2}$-islands/C cata- lysts is much higher than that in the $\mathrm{PdSn} / \mathrm{C}$ catalyst and the percentage of $\mathrm{Sn}$ (II) species for the $\mathrm{PdSn}-\mathrm{SnO}_{2}$-islands/C catalyst is obviously higher than the $\mathrm{PdSn}-\mathrm{SnO}_{2} / \mathrm{C}$ catalyst. Based on the results calculated from the atom superposition and electron delocalization molecular orbital theory, Anderson et al. proposed that the $\mathrm{Sn}(\mathrm{II}) / \mathrm{Sn}(\mathrm{IV})$ redox couple is the main factor for the generation of $(\mathrm{OH})$ ads, which can promote the oxidation of $\mathrm{CO}$ in the process of FAO.43,44 Thus, it is expected that the different percentages of tin oxides lead to different activities for these three catalysts.

Fig. 7 shows the $\mathrm{CO}$ stripping voltammograms of the $\mathrm{PdSn}-\mathrm{SnO}_{2} / \mathrm{C}, \mathrm{PdSn}-\mathrm{SnO}_{2}-$ islands/C, $\mathrm{PdSn} / \mathrm{C}, \mathrm{Pd} / \mathrm{C}$ and $\mathrm{SnO}_{2} / \mathrm{C}$ cata- lysts, where $\mathrm{CO}$ was pre-adsorbed onto the different catalysts in a $0.5 \mathrm{~mol} \mathrm{~L}^{-1} \mathrm{H}_{2} \mathrm{SO}_{4}$ solution for $5 \mathrm{~min}$. It can be seen in Fig. 7 that adsorbed $\mathrm{CO}$ has been oxidized completely in the first scan, and no $\mathrm{CO}$ oxidation is monitored during the second scan for the $\mathrm{PdSn}-\mathrm{SnO}_{2} / \mathrm{C}, \mathrm{PdSn}-\mathrm{SnO}_{2}$-islands/C, $\mathrm{PdSn} / \mathrm{C}$ and $\mathrm{Pd} / \mathrm{C}$ catalysts. $\mathrm{SnO}_{2} / \mathrm{C}$ is not active for $\mathrm{CO}$ oxidation. The onset potentials of $\mathrm{CO}$ oxidation for the three catalysts follow in the order: $\mathrm{PdSn}-\mathrm{SnO}_{2}$-islands/C o PdSn$\mathrm{SnO}_{2} / \mathrm{C}$ o $\mathrm{PdSn} / \mathrm{C}$ o $\mathrm{Pd} / \mathrm{C}$. The $\mathrm{CO}$ oxidation at the lower potential is mainly asso- ciated with the weakly adsorbed CO.45 The result indicates that the existence of $\mathrm{SnO}_{2}$ species can decrease the $\mathrm{CO}$ adsorption strength on PdSn particles. In addition, the peak potential of $\mathrm{PdSn}-\mathrm{SnO}_{2}$-islands/C has a more negative shift than that of $\mathrm{PdSn}-\mathrm{SnO}_{2} / \mathrm{C}$, suggesting that $\mathrm{PdSn}-\mathrm{SnO}_{2}$-islands/C has better tolerance to $\mathrm{CO}$ than $\mathrm{PdSn}-\mathrm{SnO}_{2} / \mathrm{C}$.

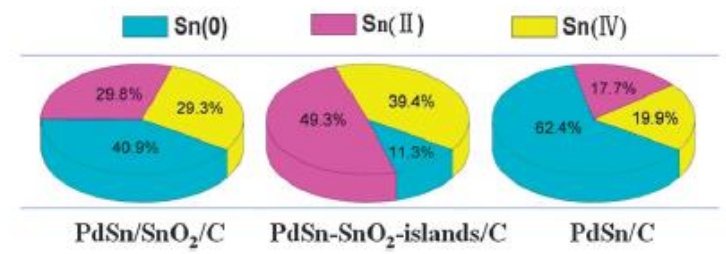

Fig. 6 Atomic ratio of $\operatorname{Sn}(0), \operatorname{Sn}($ II) and $\operatorname{Sn}(\mathrm{IV})$ species of the three catalysts. 


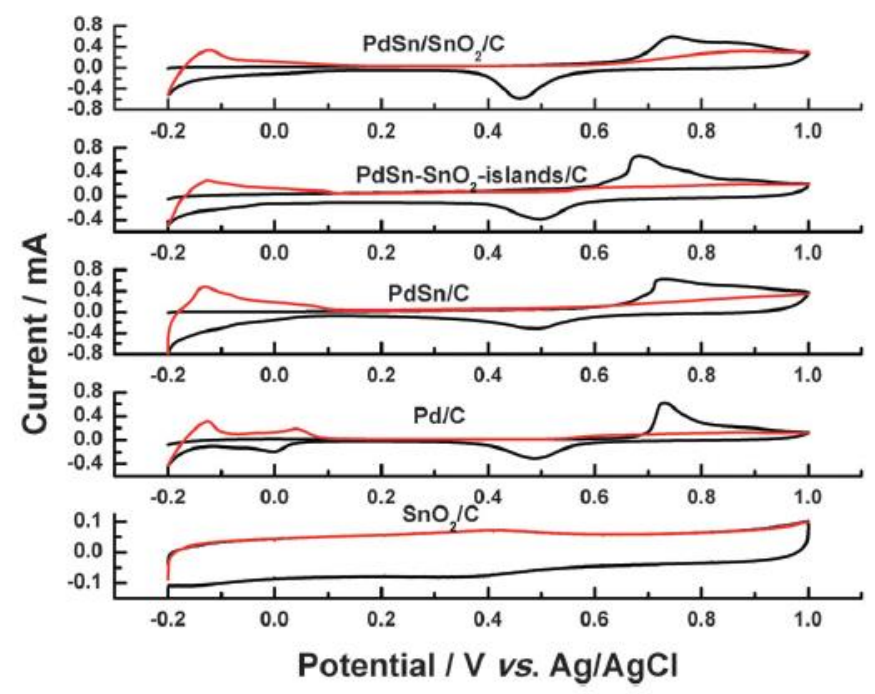

Fig. 7 The $\mathrm{CO}$ stripping voltammograms of the $\mathrm{PdSn}-\mathrm{SnO}_{2} / \mathrm{C}, \mathrm{PdSn}-\mathrm{SnO}_{2}-$ islands $/ \mathrm{C}, \mathrm{PdSn} / \mathrm{C}, \mathrm{Pd} / \mathrm{C}$ and $\mathrm{SnO}_{2} / \mathrm{C}$ catalysts in $0.5 \mathrm{~mol} \mathrm{~L}^{-1} \mathrm{H}_{2} \mathrm{SO}_{4}$ solution at a scan rate of $50 \mathrm{mV} \mathrm{s}^{-1}$.
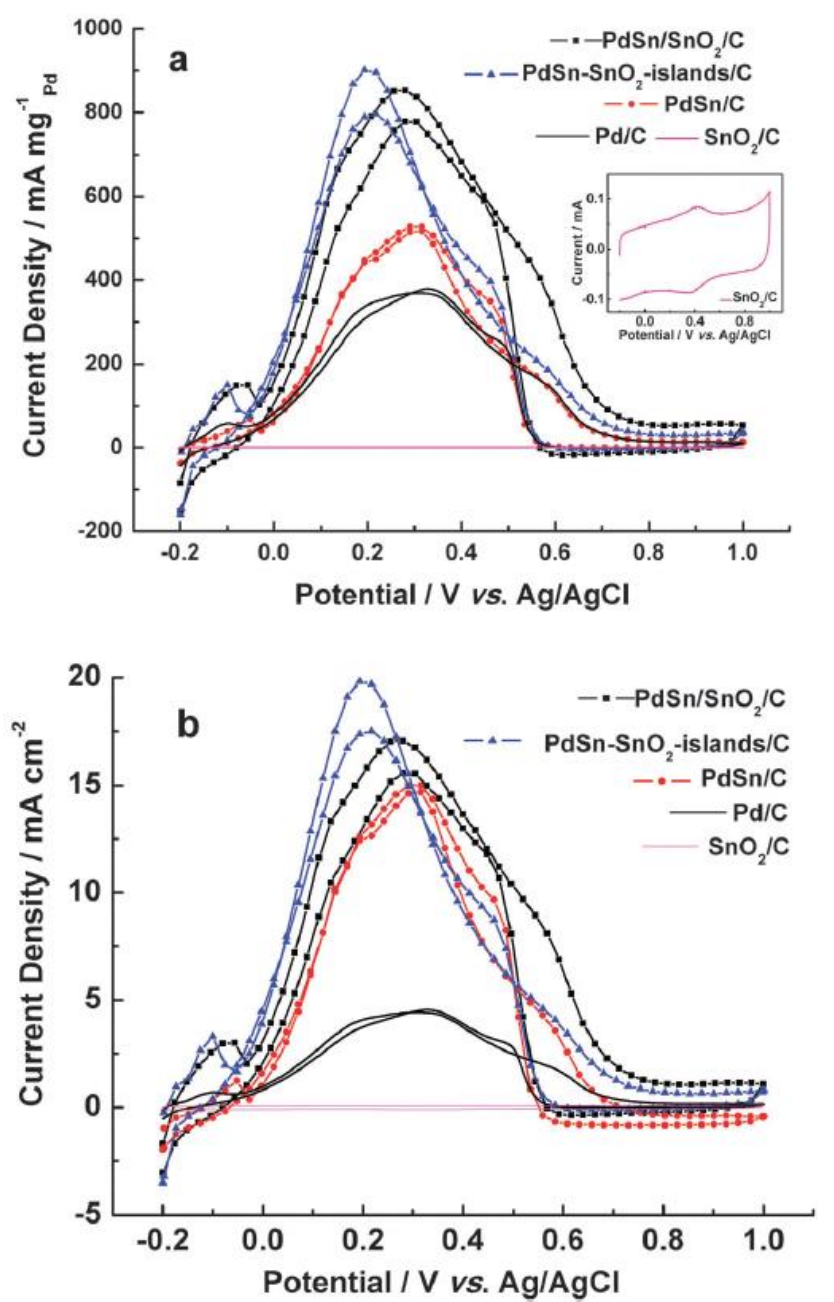

Fig. 8 Cyclic voltammograms of the $\mathrm{PdSn}-\mathrm{SnO}_{2} / \mathrm{C}, \mathrm{PdSn}-\mathrm{SnO}_{2}$-islands/C, PdSn/ $\mathrm{C}, \mathrm{Pd} / \mathrm{C}$ and $\mathrm{SnO}_{2} / \mathrm{C}$ catalysts normalized to the Pd loading on the electrodes (a) and ECSA $A_{C O}(b)$, in $0.5 \mathrm{~mol} \mathrm{~L}^{-1} \mathrm{HCOOH}+0.5 \mathrm{~mol} \mathrm{~L}^{-1} \mathrm{H}_{2} \mathrm{SO}_{4}$ solution at a scan rate $50 \mathrm{mV} \mathrm{s}^{-1}$ 
Some reports have demonstrated that $\mathrm{CO}$ oxidation is improved by tin oxide via a bifunctional mechanism.46,47 As discussed previously, the $\mathrm{Sn}(\mathrm{II}) / \mathrm{Sn}(\mathrm{IV})$ redox couple

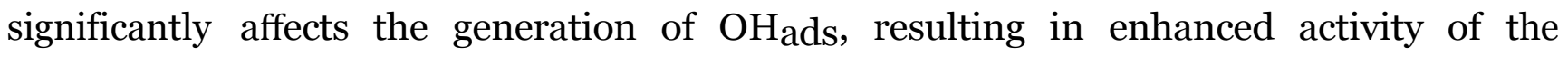
catalysts.43,44 The influence of $\mathrm{Sn}(\mathrm{II}) / \mathrm{Sn}$ (IV) on the catalytic activity and CO-tolerance were studied by Zhu's and White's groups. $39,48 \mathrm{Zhu}$ et al. showed that ethanol electrooxidation activity and $\mathrm{CO}$ tolerance can be obviously enhanced by increas- ing the $\mathrm{Sn}$ (II)/Sn(IV) ratio in the $\mathrm{PtSn} / \mathrm{C}-\mathrm{Ni}$ catalyst since the $\mathrm{Sn}(\mathrm{II}) / \mathrm{Sn}$ (IV) redox couple accelerates the transfer rate of $\mathrm{OH}_{\mathrm{ads}}{ }^{48}$ White's group suggested that reduced $\mathrm{Sn}(\mathrm{II}) \mathrm{O}$, rather than $\mathrm{Sn}(\mathrm{IV}) \mathrm{O}_{2}$, is responsible for surface CO oxidation. 39 The $\mathrm{Sn}$ (II)/ $\mathrm{Sn}$ (IV) ratios obtained from Fig. 6 are ca. 1.0 for $\mathrm{PdSn}-\mathrm{SnO}_{2} / \mathrm{C}$, ca. 1.3 for $\mathrm{PdSn}-\mathrm{SnO}_{2}$-islands/C and ca. 0.9 for $\mathrm{PdSn} / \mathrm{C}$, which result in the different CO-tolerance of these three catalysts.

The CO stripping curve was also used to evaluate the electrochemical surface area (ECSA).49 The ECSA of each catalyst is listed in Table 2. The data indicate that the ECSA of $\mathrm{PdSn}-\mathrm{SnO}_{2}$-islands/C is close to that of $\mathrm{PdSn}-\mathrm{SnO}_{2} / \mathrm{C}$, and their ECSAs are enhanced by a factor of $c a .1 .5$ and 1.9 compared with that of $\mathrm{PdSn} / \mathrm{C}$ and Pd/C catalysts, respectively. Fig. 8 shows cyclic voltammograms (CVs) of $0.5 \mathrm{~mol}$ $\mathrm{L}^{-1} \mathrm{HCOOH}$ in $0.5 \mathrm{~mol} \mathrm{~L}^{-1} \mathrm{H}_{2} \mathrm{SO}_{4}$ ambient temperature. The $\mathrm{CV}$ of $\mathrm{SnO}_{2} / \mathrm{C}$ is shown as an inset in Fig. 8a. It can be seen that $\mathrm{SnO}_{2} / \mathrm{C}$ is not active for $\mathrm{FAO}$, while two main peaks of the formic acid oxidation in both positive and negative scans with similar shapes were observed for all the other catalysts. In Fig. 8a and b, the peak potentials of $\mathrm{PdSn}-\mathrm{SnO}_{2} / \mathrm{C}, \mathrm{PdSn}-\mathrm{SnO}_{2} / \mathrm{C}$ and $\mathrm{PdSn} / \mathrm{C}$ are $0.18, \quad 0.27,0.30$ and $0.31 \mathrm{~V}$ respectively, and the current density at $0.2 \mathrm{~V}$ (see Table 2) increases in the order: $\mathrm{Pd} / \mathrm{C}$ o $\mathrm{PdSn} / \mathrm{C}$ o $\mathrm{PdSn}-\mathrm{SnO}_{2} / \mathrm{C}$ o $\mathrm{PdSn}-\mathrm{SnO}_{2}$-islands/C. The high current density and low peak potential suggest that the existence of $\mathrm{SnO}_{2}$ can enhance the catalytic activity of the PdSn alloy in FAO.50

Generally, the addition of $\mathrm{SnO}_{2}$ to noble metals for use as electrocatalytic materials results in enhanced performance because $\mathrm{SnO}_{2}$ may conveniently provide oxygen species to remove the CO-like species of oxidation residues, to free noble metal active sites.51,52 This implies that the formation of the three-phase interface between $\mathrm{SnO}_{2}, \mathrm{H}_{2} \mathrm{O}$ and noble metal is key for enhanced FAO.53 Kang et al. demonstrated that the contact between $\mathrm{Au}$ and $\mathrm{FeO}_{x}$ is the active region for $\mathrm{CO}$ oxidation, and that the activity is proportional to the amount of interfacial contact.54 In the $\mathrm{PdSn}-\mathrm{SnO}_{2}$-islands/C catalyst, $\mathrm{SnO}_{2}$ islands are in intimate contact with PdSn nanoparticles, which results in a high amount of the active sites and further leads to enhanced $\mathrm{CO}$ oxidation and FAO catalytic activity. However, it should be noted that $\mathrm{SnO}_{2}$ islands in intimate contact with PdSn nanoparticles could also occupy some active sites on the PdSn surface, so the particle size of SnO islands should have an effect on the 
catalytic activity. Therefore, according to the results of Kang et al., further work is required to optimize the size of $\mathrm{SnO}_{2}$ islands in the $\mathrm{PdSn}-\mathrm{SnO}_{2}$ system to maximize the catalytic activity in FAO.

Table 2 Electrochemical characterization of the three catalysts, the activities were obtained at $0.2 \mathrm{~V}$

\begin{tabular}{|c|c|c|c|}
\hline Catalyst & $\begin{array}{l}\mathrm{ECSA}_{\mathrm{CO}} \\
\left(\mathrm{m}^{2} \mathrm{~g}_{\mathrm{Pd}}{ }^{-1}\right)\end{array}$ & $\begin{array}{l}\text { Mass activity } \\
\left(\mathrm{mA} \mathrm{mg}_{\mathrm{Pd}}{ }^{-1}\right)\end{array}$ & $\begin{array}{l}\text { Specific activity } \\
\left(\mathrm{mA} \mathrm{cm}^{-2}\right)\end{array}$ \\
\hline $\mathrm{PdSn}-\mathrm{SnO}_{2}$-islands/C & 33.1 & 897.7 & 19.7 \\
\hline $\mathrm{PdSn}-\mathrm{SnO}_{2} / \mathrm{C}$ & 35.2 & 777.6 & 15.6 \\
\hline $\mathrm{PdSn} / \mathrm{C}$ & 21.8 & 456.9 & 12.8 \\
\hline $\mathrm{Pd} / \mathrm{C}$ & 18.1 & 342.4 & 4.4 \\
\hline
\end{tabular}

\section{Conclusions}

We have successfully prepared, via two different chemical reduction routes, $\mathrm{PdSn}-\mathrm{SnO}_{2} / \mathrm{C}$ nanoparticle catalysts with different degrees of interfacial contact. Using different stabilizers, the $\mathrm{SnO}_{2}$ nanoparticles and hybrid $\mathrm{PdSn}-\mathrm{SnO}_{2}$ nanoparticles with different morphologies were obtained. $\mathrm{PdSn}-\mathrm{SnO}_{2} / \mathrm{C}$ catalysts were found to have substantially higher $\mathrm{CO}$ tolerance and catalytic activity for formic acid oxidation than PdSn alloy catalysts, mainly due to the presence of $\mathrm{SnO}_{2}$. The different degrees of interfacial contact between $\mathrm{PdSn}$ and $\mathrm{SnO}_{2}$ influenced the catalytic activity. These results may point to a new route for preparing novel hetero- structure electrocatalysts for fuel cells.

\section{Acknowledgements}

This work was financially supported by the NSFC (21163018) and NSFPSC (20110490847 and 2012T50554).

\section{References}

1. Y. Zhu, Z. Khan and R. I. Masel, J. Power Sources, 2005, 139, 15-20. 
2. W.-L. Qu, Z.-B. Wang, Z.-Z. Jiang, D.-M. Gu and G.-P. Yin, RSC Adv., 2012, 2, 344.

3. S. Ha, R. Larsen and R. I. Masel, J. Power Sources, 2005, 144, 28-34.

4. W. Zhou and J. Y. Lee, Electrochem. Commun., 2007, 9, 1725-1729.

5. Y. Kang, L. Qi, M. Li, R. E. Diaz, D. Su, R. R. Adzic, E. Stach, J. Li and C. B. Murray, ACS Nano, 2012, 6, 2818-2825.

6. Z. L. Liu, X. H. Zhang and S. W. Tay, J. Solid State Electro- chem., 2012, 16, 545550 .

7. J. Zhang, H. Yang, K. Yang, J. Fang, S. Zou, Z. Luo, H. Wang, I.-T. Bae and D. Y. Jung, Adv. Funct. Mater., 2010, 20, 3727-3733.

8. M. Hakamada and M. Mabuchi, Mater. Trans., 2009, 50, 431-435.

9. Y. Gao, G. Wang, B. Wu, C. Deng and Y. Gao, J. Appl. Electrochem., 2011, 41, 1-6.

10. C. Du, M. Chen, W. Wang, G. Yin and P. Shi, Electrochem. Commun., 2010, 12, 843-846.

11. C. Du, M. Chen, W. Wang and G. Yin, ACS Appl. Mater. Interfaces, 2010, 3, 105109.

12. V. Mazumder, M. Chi, M. N. Mankin, Y. Liu, O. Metin, D. Sun, K. L. More and S. Sun, Nano Lett., 2012, 12, 1102-1106.

13. C. Xu, Y. Liu, J. Wang, H. Geng and H. Qiu, J. Power Sources, 2012, 199, 124-131.

14. D. Tu, B.Wu, B. Wang, C. Deng andY.Gao,Appl. Catal., B, 2011,103,163-168.

15. Z. Liu and X. Zhang, Electrochem. Commun., 2009, 11, 1667-1670.

16. Z. Zhang, J. Ge, L. Ma, J. Liao, T. Lu and W. Xing, Fuel Cells, 2009, 9, 114-120.

17. W.Xu,Y.Gao, T. Lu, Y.Tang and B. Wu, Catal. Lett., 2009, 130,312-317.

18. L. P. R. Profeti, F. C. Simões, P. Olivi, K. B. Kokoh, C. Coutanceau, J. M. L'eger and C. Lamy, J.Power Sources, 2006,158,1195-1201.

19. L. Feng, J. Yang, Y. Hu, J. Zhu, C. Liu and W. Xing, Int. J. Hydrogen Energy, 2012, 37, 48124818.

20. R. Li, H. Hao, T. Huang and A. Yu, Electrochim. Acta, 2012, 76, 292-299.

21. L. Feng, Z. Cui, L. Yan, W. Xing and C. Liu, Electrochim. Acta, 2011, 56, 2051-2056.

22. H. Lu, Y. Fan, P. Huang and D. Xu, J. Power Sources, 2012, 215, 48-52.

23. A. Kumar, A. C. Pandey and R. Prakash, Catal. Sci. Technol., 2012, 2, 2533-2538.

24. S. Huang, S. Chang, C. Lin, C. Chen and C. Yeh, J. Phys. Chem. B, 2006, 110, 23300-23305.

25. S. Huang, C. Chang, K. Wang and C. Yeh, ChemPhysChem, 2007, 8, 1774-1777.

26. Y.-C. Wei, C.-W. Liu, W.-J. Chang and K.-W.Wang, J. Alloys Compd., 2011, 509, 535-541.

27. B. Shyam, T. M. Arruda, S. Mukejee and D. E. Ramaker, J. Phys. Chem. C, 2009, 113, 19713-19721.

28. K. Wang, H. Wang, R. Wang, J. Key, V. Linkov and S. Ji, S. Afr. J. Chem., 2013, 66, 86-91.

29. W. Wang, Y. Li and H. Wang, Micro Nano Lett., 2013, 8, 23-26.

30. J. C. Jia, R. F. Wang, H. Wang, S. Ji, J. Key, V. Linkov, K. Shi and Z. Q. Lei, Catal. Commun., 2011, $16,60-63$.

31. Ü. Kersen and L. Holappa, Anal. Chim. Acta, 2006, 562, 110-114.

32. M.-R. Yang, S.-Y. Chu and R.-C. Chang, Sens. Actuators, B, 2007, 122, 269-273.

33. R. Awasthi and R. N. Singh, Int. J. Hydrogen Energy, 2012, 37, 2103-2110.

34. X.Zhao, J.Zhu, L. Liang, C. Liu, J. LiaoandW. Xing, J. Power Sources, 2012, 210, 392-396. 
35. M. Yin, Q. Li, J. O. Jensen, Y. Huang, L. N. Cleemann, N.J. BjerrumandW.Xing,J.Power Sources, 2012,219,106-111.

36. X. Zhang, H. Wang, J. Key, V. Linkov, S. Ji, X. Wang, Z. Lei and R. Wang, J. Electrochem. Soc., 2012, 159, B270-B276.

37. X. Mao, L. Yang, J. Yang, J. Key, S. Ji, H. Wang and R. Wang, J. Electrochem. Soc., 2013, 160, H219H223.

38. W. P.Zhou, A. Lewera, R. Larsen, R. I. Masel, P. S. Bagus and Wieckowski, J. Phys. Chem. B, 2006, 110, 13393-13398.

39. S. Axnanda, W. P. Zhou and M. G. White, Phys. Chem. Chem. Phys., 2012, 14, 1020710214.

40. W.-P. Zhou, S. Axnanda, M. G. White, R. R. Adzic and J. Hrbek, J. Phys. Chem. $C$, 2011, 115, 16467-16473.

41. L. Kover, Zs. Kovacs, R. Sanjines, G. Moretti, I. Cserny, G. Margaritondo, J. Palinkas and H. Adachi, Surf. Interface Anal., 1995, 23, 461-466.

42. W. Du, K. E. Mackenzie, D. F. Milano, N. A. Deskins, D. Su and X. Teng, ACS Catal., 2012, 2, 287-297.

43. A. B. Anderson, E. Grantscharova and P. Shiller, J. Electrochem. Soc., 1995, 142, 1880-1884.

44. A. B. Anderson, S. Seong and E. Grantscharova, J. Phys. Chem., 1996, 100, 1753517538.

45. Y. Kim, H. J. Kim, Y. S. Kim, S. M. Choi, M. H. Seo and W. B. Kim, J. Phys. Chem. C, 2012, 116, 18093-18100.

46. M. Arenz, V. Stamenkovic, B. Blizanac, K. Mayrhofer, N. Markovic and P. Ross, J. Catal., 2005, 232, 402-410.

47. Y. Ishikawa, M.-S. Liao and C. R. Cabera, Surf. Sci., 2000, 463, 66-80.

48. M. Zhu, G. Sun, H. Li, L. Cao and Q. Xin, Chin. J. Catal., 2008, 29, 765-770.

49. R. F. Wang, B. X. Wei, H. Wang, S. Ji, J. Key, X. T. Zhang and Z. Q. Lei, Ionics, 2011, 17, 595-601.

50. L. Feng, L. Yan, Z. Cui, C. Liu and W. Xing, J. Power Sources, 2011, 196, 2469-2474.

51. E. Antolini, F. Colmati and E. R. Gonzalez, J. Power Sources, 2009, 193, 555-561.

52. Z. Liu, D. Reed, G. Kwon, M. Shamsuzzoha and D. K. Nikles, J. Phys. Chem. C, 2007, 111, 14223-14229.

53. S. Chen, R. Si, E. Taylor, J. Janzen and J. Chen, J. Phys. Chem. C, 2012, 116, 1296912976.

54. Y. Kang, X. Ye, J. Chen, L. Qi, R. E. Diaz, V. Doan-Nguye, G. Xing, C. R. Kagan, J. Li, R. J. Gorte, E. A. Stach and B. Murray, J. Am. Chem. Soc., 2013, 135, 14991505. 